\title{
Heterogeneous Nuclear Ribonucleoprotein A/B
}

National Cancer Institute

\section{Source}

National Cancer Institute. Heterogeneous Nuclear Ribonucleoprotein A/B. NCI

Thesaurus. Code C30025.

Heterogeneous nuclear ribonucleoprotein A/B (332 aa, $\sim 36 \mathrm{kDa}$ ) is encoded by the human HNRNPAB gene. This protein plays a role in mRNA binding. 